\title{
Enrollment Issue, Power Energy Management Approach and Structure of Control of Renewable Energy Microgrid: A Review
}

\author{
Mohd Fauzi Mohamad Yusof ${ }^{l^{*}}$, Abu Zaharin Ahmad ${ }^{I}$ \\ ${ }^{1}$ Sustainable Energy \& Power Electronics Research (SUPER), Faculty of Electrical \& Electronics Engineering, \\ University Malaysia Pahang, Pekan, Pahang, Malaysia
}

Email:mohdfauzi0211@gmail.com*,zaharin@ump.edu.my

\begin{abstract}
The integration and emerging of distributed generation into the grid especially renewable energy RE source has brought solution of the problem increasing demand of electricity. The utilization of renewable energy as a source generation can minimize the effect of green house and reduce the cost of operation. The RE microgrids are the great power solution due to the capability to control and coordinate different level between the loads and generators. The energy management control is the key of successions to provide the power reliability in the RE microgrid. The problem of the optimal energy management has become widely investigated in order to achieve the optimize architecture structure of RE microgrid. Thus in this paper the details description of RE microgrid, problem issue and brief explanation about power energy management control are discussed. Furthermore, the architecture control technique of RE microgrid are elaborated and list of control technique from previous research are details. The progression project of microgrid in the world was reported and suggestion of area interest for future research activity are presented briefly.
\end{abstract}

Keywords-Renewable Energy Microgrid, Power Energy Management, Control System, Progress Project.

\section{INTRODUCTION}

The expending of the technology in energy area was bringing a new perspective of designing the electrical grid. The existing research or testbed of small distributed power generators combined with energy storage devices and integrated with existing grid bring new area of energy industry. This integrated electrical grid can be call as microgrid, minigrid or smart grid. The microgrid can be classified as a cluster of a loads, distribution generation (DG) that consist of renewable or conventional source, energy storage system (ESS) operated in grid connected or islanded. All the element will connected and control by power systems at the distribution level which is at point of common coupling. The general objective of microgrid is to design the system more intelligent, reliability, autonomous, interactive and distribute. However, the main objective of microgrid consists of schedule all unit distribution generation, energy storage and load demand with right decision of energy requirement. The microgrid must have the capability to work in reliable and economic perspective despite of high intermittent issue in islanded mode.

The new era of microgrid give the user flexibility to react and participate to the grid in order to minimize the cost and offer the user experience of energy market investment. Microgrid normally designs 
by adopted two mode of operation, which is connected to the grid or islanded grid. The microgrids are capable to switch the transmission between the modes [1][2]. In the grid connected, the power deficit can be supplied by the main grid to make sure the grid is reliable and the power generation produced can be traded with the main grid and provide the extension of energy supply to the grid if there is any uncertain event occur at the main grid. While in islanded mode, the power will be supply and control by the energy management controller even there are problem or schedule maintenance at the main grid.

\subsection{Issue and Problem of RE microgrid}

The problem issue faces within the RE microgrid technology is power reliability. Power reliability is the important outcome that needs to be provided by the electricity provider. The reliability is the main objective that needs to look at either in grid mode or islanded mode. The electrical provider needs to control all the parameter and upgrade the level of capability in order to increase the operation performance. Reliability performance can be rate by looking into average of interruption happen at consumer demand side. Normally the data will show how many frequent and duration involve when the interruption happen. Storm, equipment failure, unbalances demand-supply of energy that effect the frequency in the systems is the common reason of outage. However, the exploitations of RE microgrid give advantages to minimize the outages issue and recovery time. This happens due to intelligent control and power energy management in the system itself. Thus, the RE microgrid system normally was setup near to the targeted load therefore when interrupted occur at grid line, the consumer will not effected due to the RE microgrid can switch to islanded mode.

The RE microgrid that involve with renewable resources give a great challenge in term of reliability factor. Study in [3] was done by applying the different timeframes that work in probability method of behavior RE source and associates the timeframes with different type of renewable energy DG source according to the capacity factor. The advantages of this method are it not required detail data. The method work by calculated the different of load expected and energy balance that will minimize the running time for reliability assessment. However, the real data is needed for the system work in accurate condition. In study [4], simulation model show the microgrid with an additional DER in the grid network perform better performance in term of power reliability due to the ability to change to islanded mode when utility grid fails compare with single DER in the systems. However, the future study is needed in term of network security when the grid network is switched to islanded mode.

Other than PV and wind as a main source of renewable type of DG, the combination of thermal heat base as energy resource with other renewable source can also improve the power reliability factor in the systems. The probabilistic method can used in order to look into load, energy produce, frequency and energy surplus can be adopt in order to fulfill the load demand profile. The outages cause by the DER can be composite by the energy storage or energy reserve in the systems. Thus in [5], the probabilistic technique is proposed by looking into voltage and reactive power constraints. The system was tested by using dispatch able and wind in islanded microgrid. Apart from power reliability factor, the flexibility factor was the second issue faces in RE microgrid technology. The flexibility in RE microgrid system can be determine as capability the system minimize the impact of power interruption and perform fast recovery in order to run in normal operation condition.

The event of unpredictable of power interruption can happen because of natural disaster, cyber security attack or physical attack. Recent event such as tsunami, hurricanes, tornados, earthquakes and flood has brought attention to the power energy industry to come out with emergency action plan in order 
to observe the impact. Therefore the idea to implement the RE microgrid systems that can run isolated condition is the most critical aspect of development due to minimize the impact of power outages that occur at the main grid. The nature disaster will definitely damage the facilities or equipment and as the result, the electrical services will be interrupted. Thus, the RE microgrid will be playing the role in order to supply the electrical demand near to the community when the utility grid was isolate. Many methods was proposed in previous research for example study in [6] proposed the fuzzy logic control to impose the flexibility in the system. The flywheel energy storage model was present in [7] to provide the electrical energy to critical loads. Even though the control and the strategies the positive result interim of flexibility, the parameter in the fuzzy logic control need to be expand due to DER involve in the systems and the critical load need to determine clearly.

Thus, the strategy of restoring the service by priority load can improve the power flexibility to the overall systems in islanded or isolated operation mode. The advantages of the technique are to make sure the systems provide the available energy to the critical load and slowly back up to normal operation condition. Decentralized multi agent control method was present in [7]. The distribution agent in microgrid has flexibility to change their condition from normal condition to emergency condition when unpredictable event happen.

Power quality is the most critical issue need to be provided by the energy utility. The increase demand towards power quality was increase due to expendable of electronic application. The power quality can be improved by solving the issue such as harmonic, voltage and frequency. RE microgrid control system can provide the solution by control the load, frequency, voltage and inject the energy to the systems from energy storage in order to maintain the quality of power produce. As mention in [8], power quality compensator can be used in RE microgrid to improve the power quality issue. In [9], a grid interfacing power quality compensator is proposed and the method was applied on each DG in microgrid. Furthermore the power quality and current quality flow in the system was optimally control by using the shunt and series inverter. In [10], a three phase four wire grid interfacing power quality compensator is presented. In [11] droop control method based on reactive voltage-ampere was proposed by adopted the harmonic filtering strategy and the method control was implementing at converter of each DG. Even though the droop method control is often and widely used as a control stategy, it has also some drawbacks for example the output efficiency will minimize if each DG are unbalanced. Another strategy to composite the harmonic issue is by connected double-fed induction generator. This method was discus in [12].

\subsection{Definition of Power Energy Management Control (PEMC)}

Despite of the issue that faces by the RE microgrid technology, the power energy management control systems is the crucial part in RE microgrid. The objective of PEMC systems is to manage the power flow, minimize intermittent event happen at distribution generation, resynchronization power response to the operating mode of operation and coordinate the components parameter in the RE microgrid. In [13], the focus of the strategy of the power energy management of RE microgrid is to minimize the operation cost. The operation cost in RE microgrid can be specific as maintenance cost and electricity prices. The power energy management control strategy can be expanding to control the power outcome from the distribution generation especially renewable source. The optimal target of power energy management is to deliver power balance in the microgrid systems [14]. However, the PEMC strategy should not just focus only one 
objective function which is either in economic or power reliability. The PEMC should focus in many parameter.

Furthermore, power energy management control systems is crucial adapt in the system in order to control the intermittent of renewable source, monitoring the status of energy storage systems and load demand characteristic. The function of power energy management control systems is it can provide the near optimum within power dispatch and power demand. The load can be control by connect or disconnect according to the priority or provide the user information about the current status of energy produce. Power energy management also can solve the issue of power balance and power reliability. The PEMC can control the power capacity of the RE microgrid, electricity cost or market and load demand. As figure 1 show the history of the power energy management control system.

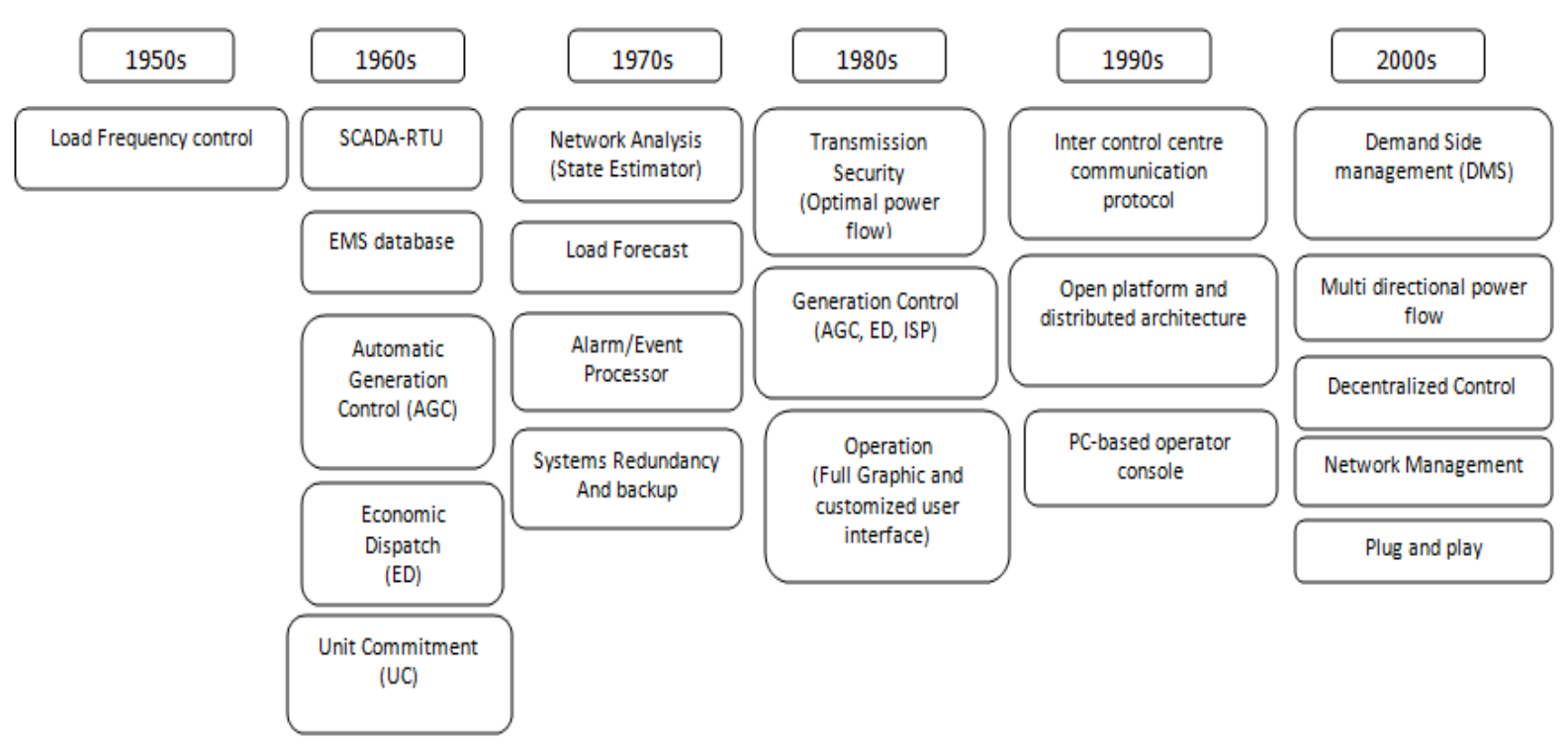

Figure 1: History of general power energy management control systems [15].

\subsection{Issue and Problem That Need To Control by Power Energy Management Control}

It is important that the power energy management control systems PEMC have capability to ensure the power reliability in the RE microgrid network and run the system in economic ways despite of issue and problem occurs during the operation. The power energy management control system need to control and monitor all the input parameter and output data that changing the value accordingly in order to make sure the RE microgrid operate in optimize condition. Therefore some of parameter are crucial and important to control or manage by PEMC. The power balance in RE microgrid is the important issue that needs to manage by the PEMC. DER or ESS unit in the RE microgrid must be able to solve the problem of unbalance power by injecting the shortage power using the energy storage systems in order to maintain the frequency and voltage in the accepted range.

Distributions energy management is another issue that needs to address by PEMC. The proper of distribution energy management give opportunity to classified load priority and use of renewable energy 
resources integrated in the RE microgrid will enhance the potential factor of power reliability and economic effectiveness by reduce the operation cost [16-17]. Thus, the economic dispatch is element need to look at in design the PEMC. The use of appropriate dispatch of DER for example renewable resources can significantly reduce the operation cost and increase the profit market of energy exchange during grid mode. While saving of cost and optimize the resources can be happen during islanded mode.

Thus, the transition between two operations needs to be done smoothly. Different control strategies need to implement for each operation mode by PEMC in order to maintain the parameter that need to control. The algorithm design in PEMC is very important in order to adjust the control strategy accordingly [18]. The PEMC become more challenging if the RE microgrid is design to operate in isolated grid network and renewable source is the main of DG in the systems.

\subsection{Purposed of Power Energy Management Control System Strategy}

In isolated or isolated mode, which is disconnected from utility grid, the RE microgrid depend on their own of distribution generation unit to meet the requirement of loads. Figure 2 show that the objective and parameter of power energy management of RE microgrid that can be control in order to provide power reliability in the systems and become smart systems.

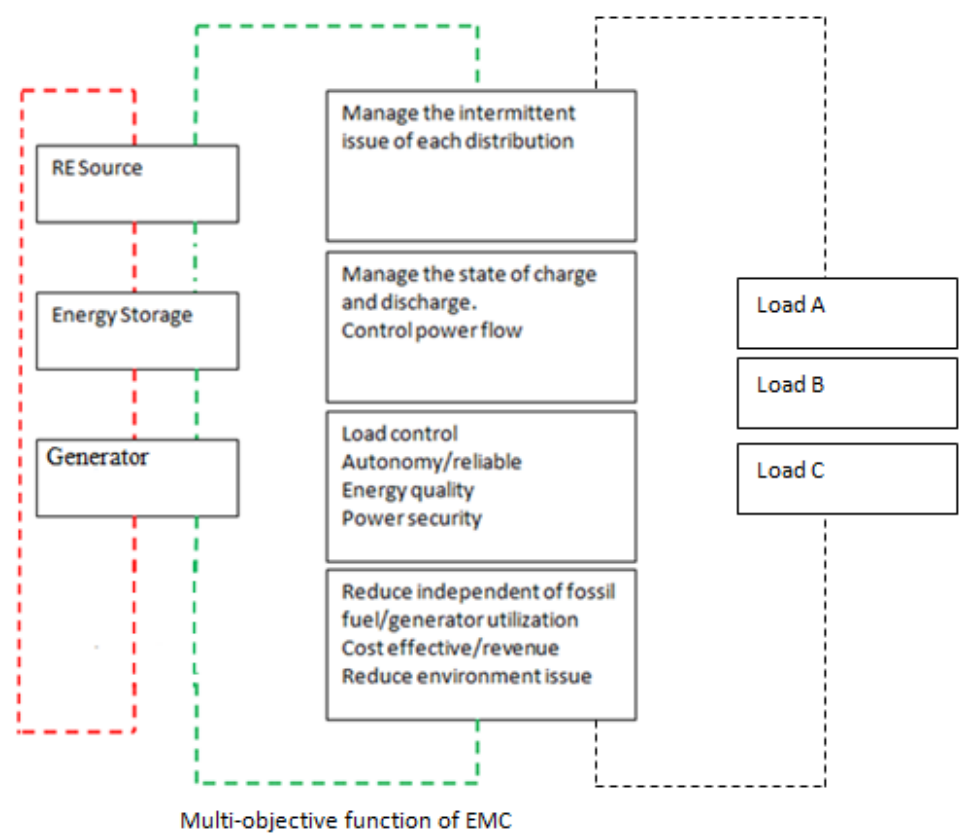

Figure 2: New approach of hybrid framework of MOPEMC for islanded and isolated RE microgrid

As previous research work, the main objective of PEMC either to manage the operation cost or provide power reliability factor by monitoring the performance of RE distribution generator in RE microgrid. However in this work, the multi objective of power energy management control strategy MOPEMC is proposed. The objective of MOPEMC is to make sure the control system strategy provide power reliability, running with load priority assessment and optimum economic analysis of RE microgrid. 
The unit forecast (UF) can be implement in designing the algorithms of MOPEMC. UF will update data information from both side which is from generation and demand side. Data that come from generation part is predict base on weather condition and demand side is unit commitment which is load requirement pattern of plant according to the specific time. The real data power that generate from distribution power and load commitment will be analysis and calculate. If the different is big after calculation with forecast data, mode of operation is change. The value of new data is set as reference and send to control systems to execute the order.

The MOPEMC will control all parameter involve in distribution generation unit and unit commitment side which is load. The unit commitment will provide the actual need of load demand and the MOPEMC will determine power need by load. The MOPEMC will calculate when is the right time to inject the power from the energy storage unit to the load based on input information. The MOPEMC capable to control the charging and discharge state of energy storage. Therefore the information given by unit commitment (input parameter) must coherent with unit forecast in order to maintain the power reliability of the plant.

In order to enhance the capability of the control, the MOPEMC can determine which operation mode to run or running the system in economic optimizing. In case of emergency or intermittent accrue, the generator will provide the support. This happens if the RE power generation unit cannot deliver enough energy to the load or energy storage unit at the minimum state. The fuel consumption will be calculated and MOPEMC can minimize the utilization of fuel by selected only to energize the critical load. The utilization of fuel is the main factor that contribute to economic saving.

The MOPEMC control must be able to control the load condition by given the priority setting to the priority load. The MOPEMC can cut off certain load if the generation side cannot deliver the power. The security algorithm parameter can be develop in MOPEMC design in order to secure the processed flow in the control system. This security function is important to make sure all the remain component in the systems for example DER unit still can function and deliver the power at least to critical load and can be control manually. The advantages of this new approach is the plant still can working and not collapse even though there is error in the system. The plant can be categories as combination architecture of centralization and decentralize RE microgrid plant system. The systems can easily be upgrade and the emergency unit of DER can easily control in default mode. 


\section{CONTROL STRUCTURE TECHNIQUE APPROACH OF MICROGRID}

\subsection{Multi-Agent Systems Control}

Multi agent system is one of the control techniques in microgrid systems. Each interface in the microgrid such as inverter, converter, load and DG are associate with an agent. The multi agent theory will coordinate element in microgrid by using communication protocol and manage the system at all layer in microgrid. They were several problem need to improve within the MAS theory such as they way data distributed, the asynchronous computerization, the capability to handle the problem occurs and communication between the agent. Study in [19], a MAS architecture is implement in a hierarchical control in a microgrid. In the study, grid agent, central agent, generation agent, load agent and breaker agent was proposed in the architecture. The architecture proposed has ability to coordinate DG and loads to maintain the stability of the operation in both mode of operation. However, the problem is the real data can be compromise when problem occurs between the agent and the system control may give wrong input information to the control system.

Hence, to solve the problem, the internet protocol communication and a MAS technology monitoring systems can ensure the safe operation of microgrid. Study in [20] shows, with the internet protocol the transition between isolated mode and grid connected become safer and stable. A hierarchical hybrid control systems is proposed in [21] where the control scheme impose three level of hierarchical control. The upper level of the control include the energy management agent, coordinated control agent in the middle level while action to restore the frequency and voltage are at lower level. It is crucial to make sure the actual frequency is maintains at the frequency reference level even through the system work in islanded mode. In study impose in [22], the secondary control was implementing in the system in order to maintain the frequency and the power exchange in with the utility grid. Eventually, the MAS was applying in the general architecture in order to optimize the operation in both mode operations.

The study in [23] show that the energy management systems using agent base technologies can improve the effectiveness of managing the power flow in the system. Study in [24], a MAS architecture was implement to coordinate the energy coordination control strategy. This energy coordination control scheme was tested in islanded mode. The control strategy can efficiently dispatch the power produced to the required loads demand when issue occurs in the system. Each agent will play their role to control the DG in order to achieve their objective function. Studies in [25] show how the MAS architecture was being used for DER management in RE microgrid in order to perform an autonomous intelligent microgrid with used of multi agent to modeling the system. However, the system become more complex when it comes too isolated RE microgrid.

The comparison between centralized and decentralized approach of control architecture topology of microgrid was discuss in study [26]. The discussions focus more on cooperative behavior between the agents in microgrid. While study in [27] proposed that the MAS architecture control provide the smooth transition from grid connected to islanded mode during disturbance. Study in [28] proposed the MAS architecture for optimizing the DR by control the customer load according to the grid generation resources. The objective of the architecture is to reduce the cost of operation and avoid overload during peak hour. Overall, it can be seen that the MAS architecture control was conducted more at microgrid that connect to the main grid network either run in islanded mode. Although in isolated mode or the RE microgrid that function off grid, it is more crucial and complicated. 


\subsection{Voltage and Frequency Control}

Normally droop method was used to control the voltage and the frequency in the RE microgrid. Most of the generation distribution unit was not the synchronous generator type, therefore the droop technique can control the generator in order to synchronize. To avoid communication protocol, the conventional frequency-voltage droop method was proposed in [29] and implement to control batteries and inverter. Study in [30] suggest that, the conventional droop control was use to modify current that allow converter to work in several modes such as grid connected or islanded. The study in [31] shows that the voltage active power and the frequency reactive power was depend by low voltage network. Therefore in order to maintain the frequency in the systems, the reference of sine wave generator is needed to emulate the utility grid phase voltage.

As discuss in [32], they was two approach methods in term of power sharing. The first approach was not required communication between DGs, where the feedback was transform into matrix based on the line resistance and reactance ratio while second approach required minimum communication. The converter output voltage reference was modified to suit the active and reactive power in the power line. The info provides can facilitated the power flow in the system and make the power sharing more efficient. In [33], a power droop control adapted with derivative controller was proposed. This control was design to work in islanded mode and pseudo droop control method in microgrid was discuss in [34] to control the energy among the DG by using the variation of frequency as an agent communication. Study in [35], impose the energy management control system while adopt the droop control technique. The objective of the EMCS is to minimize the fuel consumption and ensure the flexibility of the operation. The droop characteristic will be modifying according to the current constraints.

The study in [36] proposed a dynamic model of flywheel energy storage systems. This method was used to solve the problem create by wind generation by control the power exchange between power interface with the utility grid. The three mode was impose in the systems which is voltage control, frequency control and power stability. The result show the method proposed has the capability to handle the power fluctuation of wing generation. In [37], a voltage and frequency control is applied to double fed induction generator is another method was proposed to improve voltage regulation and minimize impact of frequency change during islanded mode. While study in [38], proposed an adaptive droop control for energy storage systems in microgrid. The higher condition of charging state will deliver more power to the systems.

An islanded droop controlled microgrid was proposed in [39. The objective is to minimize the utilization of fuel and ensure the stability of the operation. The method was done by control the output power of DG towards droop stability analysis, droop selection and generator optimization. In [40], a small signal model of droop based generation control was proposed. The method was implementing at the DG inverter which control the active power, frequency and voltage in the decentralized microgrid. While study in [41] proposed an angle droop control loop with interfaced DG converter.

The control of renewable energy, energy storage systems, variable load and AC grid connection can be categories as parameter control in operation strategy control in mocrogrid. The strategy can be divided in three modes which is normal mode when DC voltage control and power balancing was done by converter, recovery mode when coordinated the DG during grid fault and used ESS to composite energy and islanded mode for proper load shedding. 


\subsection{Adaptive Control and Control of Power Flow}

Adaptive control is one of the control strategies to control the uncertain and varying parameters. The objective of the adaptive control is to maintain the performance consistency of systems. As microgrid the adaptive control can deal with unpredictable event at load demand, disturbance at utility grid or generation that involve renewable source as generation type. Study in [42], an adaptive control using swarm intelligence technique was presented. The objective of the control method is to control the frequency and voltage in the outer power loop and inner current loop. The swarm intelligence technique was used to enhance the power quality in the microgrid by auto tuning the controller. In [43], an adaptive control of microgrid inverter based on local parametric optimization was proposed. A mathematical model was design in form of transfer function to perform the smooth interface with the main grid. The objective of the controller topology is to minimize the error between the actual data with the reference setting point and leads the systems to low harmonic distortion.

In [44], a control strategy for microgrid inverters based on adaptive three orders sliding mode and optimized droop controls was presented. The control structure is design based on the inner adaptive three order sliding mode close loop, the immediate virtual output impedance loop, and outer power loop. The proposed method reduces the line inductive and improves the power sharing accuracy.

Studies in [45] used an adaptive control strategy to monitor the performance by looking into response of controlled devices and temporarily modulate the control set point in order to tracking the set point during the disturbances. The paper presents the detail analysis of overall behavior of the system. The second order transfer function was used to verify the strategy method that has ability to response with limit or over the limit of the set point. In [46], an adaptive control method was present for DC microgrid. The adaptive method was used to coordinate the converter, DER and switched control in DC microgrid. While study in [47], an adaptive control is combine with PI controller and a PSO fuzzy system to regulate the frequency in the systems.

It is important to design the power flow control strategy when utility grid is doing the off power schedule maintenance or have long period of disturbance. It is important to make sure the power flow still the same even the utility grid is scheduled. Study in [48] proposed the power flow control scheme between the utility and the microgrid. The control approach is using back to back converter that isolate frequency between two mode conditions. With this converter, the fluctuated frequency at utility grid did not affected the power at microgrid side. The converter used the local data of DG to operate where no communication was required for power load sharing. The superconducting magnetic energy storage systems controller was proposed in [49]. The objective of the controller is to control power flow of windhybrid microgrid and stabilize the operation.

While in [50] DSTATCOM was used and combine with the superconductor energy storage systems to enhance the stability and control the power flow of microgrid working with the wind generation. In [51] the concept of smart transformer was present. The control concept is control the power transfer at point of commune connection. The control method is control the active power exchange between the utility grid and the microgrid. 


\section{PROGRESSION OF PROJECT AND FUTURE RESEARCH IN MICROGRID}

\subsection{Progression Project of Microgrid and Future Research in Microgrid}

Microgrids promise a good solution in providing the energy. The microgrid application was the best to be implementing in critical area like hospital, servers and rural areas. Many organisms like CERTS in US, Power System Engineering Research Center (PSERC), British Columbia Institute of Technology (BCIT) in Canada, New Energy and Industrial Technology Development Organization (NEDO) in Japan take further action in develop the research program of development the microgrids/RE microgrid technology. The aim of the project is to investigate, developing and validating the operational of the microgrid. The project also needs to determine the effectiveness of the controller use, the protection and the security parameter require in the microgrid [52]. The table 2 to 4 indicates some ongoing project and testbeds of microgrid. The main study in the microgrid was involving with the standardization and benchmarking factor, study of the impact on the operation power system, alternative network design and ect [53].

There is several area of interest for the future research in the microgrid technology. The gaps in the technical issue aspect need further research by the researcher in order to improve and enhance the potential of microgrid. The protection control aspect of microgrid is the critical issue that need to solve. The traditional protection systems for the traditional grid systems need to be upgrade and adapt with the characteristic, parameter and variability of DER integrated in the microgrid. The new technology of protection devices needs to adapt and capable to work under the intermittent and uncertainty factor that create by DER in the microgrid or impose by the nature.

The DC microgrid is another interest topic to look at. Reduce loses, nonreactive power flow and no need synchronization are the interest example factor of DC distribution. However, this technology needs future attention due to their complexity of power electronic systems. The optimal operation control in microgrid is the key element in the microgrid systems. The microgrid systems need to comply with several parameter or mode condition in order to optimal the operation. The energy management control in microgrid is the important control in order to coordinate DG, energy storage systems and load management. The structure and the element of control were discussed in section 4. However, the research afford still needed in order to full fill the requirement to optimize the microgrid operation. 
Table 2: summary of microgrid project at North America [54-55]

\begin{tabular}{llllll}
\hline \multicolumn{1}{c}{ Region } & \multicolumn{1}{c}{ Microgrid } & \multicolumn{1}{c}{ DG } & DES & Load & Control \\
\hline North America & $\begin{array}{l}\text { British } \\
\text { Columbia } \\
\text { Boston Bar. }\end{array}$ & Hydro & N/A & Residential & Centralized \\
& $\begin{array}{l}\text { Hydro Boralex, } \\
\text { Canada. }\end{array}$ & Diesel Generator & N/A & Residential & Centralized \\
& $\begin{array}{l}\text { CERTS, US. } \\
\text { Diesel Generator }\end{array}$ & Battery & $\begin{array}{l}\text { Static, induction } \\
\text { motor }\end{array}$ & Decentralized \\
& $\begin{array}{l}\text { University of } \\
\text { Wisconsin- } \\
\text { Madison, US. }\end{array}$ & $\begin{array}{l}\text { Gener } \\
\text { Biodiesel } \\
\text { Genset, } \\
\text { Microturbine, } \\
\text { Mad River, } \\
\text { Paitsfield, }\end{array}$ & N/A & Static & Centralized \\
& Vermont. & N/A & Industrial & Contralized \\
& & & & \\
\hline
\end{tabular}

Table 3: Summary of microgrid project at Asia [54-55]

\begin{tabular}{|c|c|c|c|c|c|}
\hline Region & Microgrid & DG & DES & Load & Contro \\
\hline \multirow[t]{7}{*}{ Asia } & $\begin{array}{l}\text { Shimizu, } \\
\text { Japan }\end{array}$ & Gas turbine & $\begin{array}{l}\text { Battery, } \\
\text { Supercapacitor }\end{array}$ & Residential & Centralized \\
\hline & $\begin{array}{l}\text { Hachinohe, } \\
\text { Japan }\end{array}$ & $\begin{array}{l}\text { PV, Wind, } \\
\text { Diesel } \\
\text { Genset, CHP }\end{array}$ & Battery & $\begin{array}{l}\text { Industrial } \\
\text { Commercial }\end{array}$ & Centralized \\
\hline & $\begin{array}{l}\text { Kyoto Eco- } \\
\text { Energy, Japan }\end{array}$ & $\begin{array}{l}\text { PV, Wind, } \\
\text { Fuel Cell, } \\
\text { Biogas }\end{array}$ & Battery & $\begin{array}{l}\text { Residential } \\
\text { Industrial }\end{array}$ & Centralized \\
\hline & Aichi, Japan & $\begin{array}{l}\text { PV, Fuel Cell } \\
\text { PV, Fuel }\end{array}$ & Battery & Commercial & Centralized \\
\hline & Sendai, Japan & $\begin{array}{l}\text { Cell, Gas } \\
\text { turbine }\end{array}$ & Battery & $\begin{array}{l}\text { Residential } \\
\text { Industrial } \\
\text { Commercial }\end{array}$ & Centralized \\
\hline & $\begin{array}{l}\text { Hsingchiang, } \\
\text { China }\end{array}$ & $\begin{array}{l}\text { PV, Diesel } \\
\text { Genset }\end{array}$ & Battery & $\begin{array}{l}\text { Residential } \\
\text { Commercial }\end{array}$ & Centralized \\
\hline & $\begin{array}{l}\text { Hefei } \\
\text { University of } \\
\text { Technology, } \\
\text { China }\end{array}$ & $\begin{array}{l}\text { PV, Wind, } \\
\text { Diesel } \\
\text { Genset, } \\
\text { Hydro }\end{array}$ & $\begin{array}{l}\text { Battery, } \\
\text { Supercapacitor }\end{array}$ & Static Motor & Centralized \\
\hline
\end{tabular}


Table 4: Summary of microgrid project at Europe [54-55]

\begin{tabular}{|c|c|c|c|c|c|}
\hline Region & Microgrid & DG & DES & Load & Control \\
\hline \multirow[t]{8}{*}{ Europe } & Kythnos, Greece & $\begin{array}{l}\text { PV, } \\
\text { Genset }\end{array}$ & Battery & Residential & Centralized \\
\hline & $\begin{array}{l}\text { Labein } \\
\text { Experimental } \\
\text { Centre }\end{array}$ & $\begin{array}{l}\text { Wind, PV, } \\
\text { Microturbine, } \\
\text { Diesel Genset }\end{array}$ & $\begin{array}{l}\text { Battery, } \\
\text { Supercapacitor, } \\
\text { Flywheel }\end{array}$ & Static & $\begin{array}{l}\text { Centralized and } \\
\text { De centralized }\end{array}$ \\
\hline & & $\begin{array}{l}\text { PV, Wind, CHP, } \\
\text { Diesel Genset }\end{array}$ & $\begin{array}{l}\text { Battery, } \\
\text { Supercapacitor, }\end{array}$ & Static & Centralized \\
\hline & $\begin{array}{l}\text { Lab-scale } \\
\text { Testbed, } \\
\text { University of } \\
\text { Leuven, } \\
\text { Belgium }\end{array}$ & PV, CHP & $\begin{array}{l}\text { Flywheel } \\
\text { Battery }\end{array}$ & Static & Centralized \\
\hline & $\begin{array}{l}\text { Continuon } \\
\text { Holiday Park, } \\
\text { Netherlands }\end{array}$ & PV & Battery & Residential & Centralized \\
\hline & $\begin{array}{l}\text { Demotec, } \\
\text { Germany }\end{array}$ & $\begin{array}{l}\text { PV, Wind, CHP, } \\
\text { Diesel Genset }\end{array}$ & Battery & $\begin{array}{l}\text { Residential } \\
\text { Commercial }\end{array}$ & Centralized \\
\hline & $\begin{array}{l}\text { Am Steinweg, } \\
\text { Germany }\end{array}$ & PV, CHP & Battery & Residential & Centralized \\
\hline & $\begin{array}{l}\text { Lab-scale } \\
\text { testbed, National } \\
\text { Technical } \\
\text { University of } \\
\text { Athens, Greece }\end{array}$ & PV, Wind & Battery & Static & Centralized \\
\hline
\end{tabular}

\section{CONCLUSION}

RE Microgrid can be classified as future energy production. This paper has discussed brief review of control existing technique of RE microgrid. Recent progress shows that, the centralized control architecture was used widely on ongoing project or testbed systems. The plug and play capability is the most interest factor in decentralized control approach due to the simplicity of expands the systems. The exploitation of renewable energy as a components distribution energy resources will enhanced the potential of microgrid toward friendly environment. Therefore, the energy management control system is the key element to ensure the successfulness operation of microgrid plant. The main objective of power energy management control is to make sure the plant is power reliable and function in economic way. Several control technique and approach was discus and explained briefly in section 2 . 
Finally, they are still gap of interest areas need to fill in term of development of microgrid technology system. The example area needs to establish is DC and AC element control, renewable energy distribution control that integrates in the RE microgrid and optimal operation of the whole systems.

\section{REFERENCES}

[1]E. Alvarez, A. C. Lopez, J. Gómez-Aleixandre, and N. de Abajo, "On-line minimization of running costs, greenhouse gas emissions and the impact of distributed generation using microgrids on the electrical system," in Proc. IEEE PES/IAS Conference on Sustainable Alternative Energy (SAE), Sept. 2009, pp. 1-10.

[2]An Overview of SENDAI Experimental Study Project Experimental Study Project - Power feeding test with Multiple quality levels, K. Hirose, IEEE International Telecommunications Energy Conference (INTELEC2005). September 20, 2005.

[3] B. Falahati, A. Kargarian, and Y. Fu, "Timeframe capacity factor relia- bility model for isolated microgrids with renewable energy resources," in Proc. IEEE Power Energy Soc. General Meeting, Jul. 2012, pp. 1-8.

[4] H. Daneshi and H. Khorashadi-Zadeh, "Microgrid energy management system:Astudy of reliability and economic issues," in Proc. IEEE Power Energy Soc. General Meeting, Jul. 2012, pp. 1-5.

[5] H. E. Farag, M. M. A. Abdelaziz, and E. F. El-Saadany, "Voltage and reactive power impacts on successful operation of islanded microgrids," IEEE Trans. Power Syst., vol. 28, no. 2, pp. 1716-1727, May 2013.

[6] S. Cano-Andrade, M. R. von Spakovsky, A. Fuentes, C. L. Prete, B. F. Hobbs, and L. Mili, “Multiobjective optimization for the sustainable-resilient synthesis/design/operation of a power network coupled to distributed power producers via microgrids," in Proc. ASME Int. Mech. Eng. Congr. Expo., vol. 6. 2012, pp. 1393-1408.

[7] R. Arghandeh, M. Pipattanasomporn, and S. Rahman, "Flywheel energy storage systems for ridethrough applications in a facility microgrid," IEEE Trans. Smart Grid, vol. 3, no. 4, pp. 1955-1962, Dec. 2012.

[8] R. M. Kamel, A. Chaouachi, and K. Nagasaka, "RETRACTED: Wind power smoothing using fuzzy logic pitch controller and energy capacitor system for improvement micro-grid performance in islanding mode," Energy, vol. 35, no. 5, pp. 2119-2129, 2010.

[9] Y.W. Li, D. M. Vilathgamuwa, and P. C. Loh, "A grid-interfacing power quality compensator for three-phase three-wire microgrid applications," IEEE Trans. Power Electron., vol. 21, no. 4, pp. 10211031, Jul. 2006.

[10] Y. Li, D. M. Vilathgamuwa, and P. C. Loh, "Microgrid power qual- ity enhancement using a threephase four-wire grid-interfacing com- pensator,' IEEE Trans. Ind. Appl., vol. 41, no. 6, pp. 1707-1719, Nov./Dec. 2005.

[11] T.-L. Lee and P.-T. Cheng, "Design of a new cooperative harmonic filter- ing strategy for distributed generation interface converters in an islanding network," IEEE Trans. Power Electron., vol. 22, no. 5, pp. 1919-1927, Sep. 2007.

[12] F. Wei, D. M. Vilathgamuwa, and S. S. Choi, "Mitigation of harmonics of DFIGs in DCmicrogrids,' in Proc. IEEE Energy Convers. Congr. Expo. (ECCE), Sep. 2012, pp. 1946-1953.

[13] C. A. Hernandez-Aramburo, T. C. Green, and N. Mugniot, "Fuel consumption minimization of a microgrid," IEEE Trans. Ind. Appl., vol. 41,no. 3, pp. 673-681, May/Jun. 2005.

[14] R. Firestone and C. Marnay, "Energy manager design for microgrids," CERTS, Calif. Energy Comm., Sacramento, CA, LBNL-54447, 2005. 
[15]H. Lee Smith, A Brief History of Electric Utility Automation Systems, April 2010, ELECTRIC ENERGY T\&D MAGAZINE,at http://www.electricenergyonline. com/?page=show_article\&mag= $63 \&$ article $=491$.

[16] C. Wang and M. Nehrir, "Power management of a stand-alone wind/ photovoltaic/fuel cell energy system," IEEE Trans. Energy Convers., vol. 23, no. 3, pp. 957-967, Sep. 2008.

[17] C. Alvial-Palavicino, N. Garrido-Echeverría, G. Jiménez-Estévez, L. Reyes, and R. Palma-Behnke, "A methodology for community engagement in the introduction of renewable based smart microgrid," Energy for Sustainable Development, vol. 15, no. 3, pp. 314-323, 2011.

[18] H. Karimi, "Islanding Detection and Control of an Islanded Electron- ically-Coupled Distributed Generation Unit," Ph.D., Univ. Toronto, Dept. of Electr. \& Comput. Eng., , 2007.

[19] N. Cai, X. Xu, and J. Mitra, "A hierarchical multi-agent control scheme for a black start-capable microgrid," in Proc. IEEE Power Energy Soc. General Meeting, Jul. 2011, pp. 1-7.

[20] T. Li, Z. Xiao, M. Huang, J. Yu, and J. Hu, "Control system simulation of microgrid based on IP and multi-agent," in Proc. Int. Conf. Inf., Netw. Autom. (ICINA), vol. 1. Oct. 2010, pp. V1-235-V1-239. [21] F. Shahnia, R. Majumder, A. Ghosh, G. Ledwich, and F. Zare, "Operation and control of a hybrid microgrid containing unbalanced and nonlinear loads,' Electr. Power Syst. Res., vol. 80, no. 8, pp. 954965, Aug. 2010.

[22] J. Jimeno, J. Anduaga, J. Oyarzabal, and A. G. de Muro, "Architecture of a microgrid energy management system,'’ Eur. Trans. Elect. Power, vol. 21, no. 2, pp. 1142-1158, Mar. 2011.

[23] J. Oyarzabal, J. Jimeno, J. Ruela, A. Engler, and C. Hardt, "Agent based micro grid management system," in Proc. Int. Conf. Future Power Syst., Nov. 2005, pp. 1-6.

[24] D. Shao, Q. Wei, and T. Nie, "A multi-agent control strategy in micro- grid island mode," in Proc. 6th Int. Forum Strategic Technol., vol. 1. Aug. 2011, pp. 429-432.

[25] T. Logenthiran, D. Srinivasan, and D. Wong, "Multi-agent coordination for DER in MicroGrid,' in Proc. IEEE Int. Conf. Sustain. Energy Technol., Nov. 2008, pp. 77-82.

[26] C. M. Colson and M. H. Nehrir, "Algorithms for distributed decision- making for multi-agent microgrid power management,'” in Proc. IEEE Power Energy Soc. General Meeting, Jul. 2011, pp. 1-8.

[27] M. Pipattanasomporn, H. Feroze, and S. Rahman, "Multi-agent sys- tems in a distributed smart grid: Design and implementation," in Proc. IEEE/PES Power Syst. Conf. Expo., Mar. 2009, pp. 1-8.

[28] D. Chen and L. Xu, "Autonomous DC voltage control of a DC microgrid with multiple slack terminals," IEEE Trans. Power Syst., vol. 27, no. 4, pp. 1897-1905, Nov. 2012.

[29] F. D. Kanellos, A. I. Tsouchnikas, and N. D. Hatziargyriou, "Micro-grid simulation during gridconnected and islanded modes of operation," in Proc. Int. Conf. Power Syst. Transients, vol. 6. 2005, pp. $19-23$.

[30] P. Arboleya et al., "An improved control scheme based in droop charac- teristic for microgrid converters,' Electr. Power Syst. Res., vol. 80, no. 10, pp. 1215-1221, Oct. 2010.

[31] H. Laaksonen, P. Saari, and R. Komulainen, "Voltage and frequency control of inverter based weak LVnetwork microgrid,' in Proc. Int. Conf. Future Power Syst., Nov. 2005, pp. 1-6.

[32] R. Majumder, G. Ledwich, A. Ghosh, S. Chakrabarti, and F. Zare, "Droop control of converterinterfaced microsources in rural distributed genera- tion,' IEEE Trans. Power Del., vol. 25, no. 4, pp. 2768-2778, Oct. 2010.

[33] J. Kim, J. M. Guerrero, P. Rodriguez, R. Teodorescu, and K. Nam, "Mode adaptive droop control with virtual output impedances for an inverter- based flexible AC microgrid," IEEE Trans. Power Electron., vol. 26, no. 3, pp. 689-701, Mar. 2011.

[34] E. Serban and H. Serban, "Acontrol strategy for a distributed power gen- eration microgrid application with voltage- and current-controlled source converter,' IEEE Trans. Power Electron., vol. 25, no. 12, pp. 2981-2992, Dec. 2010.

[35] E. Barklund, N. Pogaku, M. Prodanovic, C. Hernandez-Aramburo, and T. C. Green, "Energy management system with stability constraints for stand-alone autonomous microgrid," in Proc. IEEE Int. Conf. Syst. Syst. Eng., Apr. 2007, pp. 1-6. 
[36] G. O. Suvire, M. G. Molina, and P. E. Mercado, "Improving the inte- gration of wind power generation into AC microgrids using flywheel energy storage,' IEEE Trans. Smart Grid, vol. 3, no. 4, pp. 1945-1954, Dec. 2012.

[37] M. Shahabi, M.-R. Haghifam, M. Mohamadian, and S. A. Nabavi-Niaki, "Microgrid dynamic performance improvement using a doubly fed induction wind generator,' IEEE Trans. Energy Convers., vol. 24, no. 1, pp. 137-145, Mar. 2009.

[38] X. Lu, K. Sun, J. M. Guerrero, J. C. Vasquez, and L. Huang, "State-of- charge balance using adaptive droop control for distributed energy stor- age systems in DC microgrid applications," IEEE Trans. Ind. Electron., vol. 61, no. 6, pp. 2804-2815, Jun. 2014.

[39] E. Barklund, N. Pogaku, M. Prodanovic, C. Hernandez-Aramburo, and T. C. Green, "Energy management in autonomous microgrid using stability-constrained droop control of inverters," IEEE Trans. Power Electron., vol. 23, no. 5, pp. 2346-2352, Sep. 2008.

[40] G. Venkataramanan and M. Illindala, "Small signal dynamics of inverter interfaced distributed generation in a chain-microgrid," in Proc. IEEE Power Eng. Soc. General Meeting, Jun. 2007, pp. 1-6.

[41] R. Majumder, B. Chaudhuri, A. Ghosh, R. Majumder, G. Ledwich, and F. Zare, "Improvement of stability and load sharing in an autonomous microgrid using supplementary droop control loop," IEEE Trans. Power Syst., vol. 25, no. 2, pp. 796-808, May 2010.

[42] International Journal of Scientific \& Engineering Research, Volume 5, Issue 1, January-2014 1945 ISSN 2229-5518 IJSER (C) 2014 http://www.ijser.org An Adaptive Control for Autonomous Micro-Grid Using Swarm Intelligence Technique J.Eswari, Dr.S.Jeyadevi.

[43] Adaptive Control of Micro-grid Inverters Based on Local Parametric Optimization Vladimir Nikulin and Viktor Ten State University of New York, USA, Nazarbayev University, Kazakhstan.

International Journal of Engineering and Innovative Technology (IJEIT) Volume 3, Issue 9, March 2014 [44] Yancheng Liu, , Qinjin Zhang, , Chuan Wang, , Ning Wang "A control strategy for microgrid inverters based on adaptive three-order sliding mode and optimized droop controls"Electric Power Systems Research Volume 117, December 2014, Pages 192-201

[45] A. Mehrizi-Sani and R. Iravani, "Online set point modulation to enhance microgrid dynamic response: Theoretical foundation,'” IEEE Trans. Power Syst., vol. 27, no. 4, pp. 2167-2174, Nov. 2012.

[46] D. Salomonsson, L. Soder, and A. Sannino, "An adaptive control system for a DC microgrid for data centers,” IEEE Trans. Ind. Appl., vol. 44, no. 6, pp. 1910-1917, Nov./Dec. 2008.

[47] H. Bevrani, F. Habibi, P. Babahajyani, M. Watanabe, and Y. Mitani, "Intelligent frequency control in an AC microgrid: Online PSO-based fuzzy tuning approach," IEEE Trans. Smart Grid, vol. 3, no. 4, pp. 1935-1944, Dec. 2012.

[48] R. Majumder, A. Ghosh, G. Ledwich, and F. Zare, "Power management and power flow control with back-to-back converters in a utility con- nected microgrid,' IEEE Trans. Power Syst., vol. 25, no. 2, pp. 821-834, May 2010.

[49] M. G. Molina and P. E. Mercado, "Power flow stabilization and control of microgrid with wind generation by superconducting magnetic energy storage," IEEE Trans. Power Electron., vol. 26, no. 3, pp. 910-922, Mar. 2011.

[50] M. G. Molina and P. E. Mercado, "Stabilization and control of tie- line power flow of microgrid including wind generation by distributed energy storage,' Int. J. Hydrogen Energy, vol. 35, no. 11, pp. 5827-5833, Jun. 2010.

[51] T. L. Vandoorn, J. D. M. De Kooning, B. Meersman, J. M. Guerrero, and L. Vandevelde, "Voltagebased control of a smart transformer in a microgrid,' IEEE Trans. Ind. Electron., vol. 60, no. 4, pp. 12911305, Apr. 2013.

[52] Sanchez M. Overview of microgrid research and development activities in the European Union. In: Symposium on microgrids.

[53] Hatziargyriou N. Advanced architectures and control concepts for more microgrids. Technical Report, European Commission; 2009.

[54]N.W.A. Lidula and A.D. Rajapakse, 2011, Microgrids Research: A Review of Experimental Microgrids and Test Sys- tems, Renewable and Sustainable Energy Reviews, 15 at 186-202. 
[55]M. Barnes, J. Kondoh, H. Asano, J. Oyarzabal, G. Ventakaramanan, R. Lasseter,N. Hatziargyriou and T. Green, Real-World MicroGrids: An Overview,in: IEEE InternationalConference on System of Systems Engineering, San Antonio, April, 2007.

[56]F. Katiraei, R. Hatziargyriou and A.N. Dimeas, 2008, "Microgrids Management",IEEE Power \& Energy Magazine, 6 (3) at 54-65.

[57] Guerrero J, Vasquez J, Teodorescu R. Hierarchical control of droop- controlled dc and ac microgrids: a general approach towards standardiza- tionIEEE Industrial Electronics (IECON) 2009:4305-10.

[58]Vasquez J, Guerrero J, Miret J, Castilla M, de Vicun a L. Hierarchical control of intelligent microgrids. IEEE Industrial Electronics Magazine 2010;4(4):23-9.

[59]Vasquez J, Guerrero J, Savaghebi M, Teodorescu R. Modeling, analysis, and design of stationary reference frame droop controlled parallel three-phase voltage source inverters. In: International conference on power electronics (ECCE); 2011. p. 272-9.

[60]Mohamed Y, Radwan A. Hierarchical control system for robust microgrid operation and seamless mode transfer in active distribution systems. IEEE Transactions on Smart Grid 2011;2(2):352-62.

[61] M. Prodanovic and T. C. Green, "High-quality power generation through distributed control of a power park microgrid," IEEE Trans. Ind. Electron., vol. 53, no. 5, pp. 1471-1482, Oct. 2006.

[62]W. Liu, J. Sarangapani, G.K. Venayagamoorthy,D. Wunsch, M.L. Crow, L.Liu and D.A. Cartes, "Neural Network Based Decentralized Controls of Large Scale Power Systems", in: IEEE 22 ${ }^{\text {nd }}$ International Symposium on IntelligentControl, Singapore, Oct., 2007, at 676-681.

[63]Jimeno J, Anduaga J, Oyarzabal J, de Muro A. "Architecture of a microgrid energy management system”. European Transactions on Electrical Power 2011;21(2):1142-58.

[64]Gil N, Lopes J. "Hierarchical frequency control scheme for islanded multi- microgrids operation. "Power Tech 2007:1-6.

[65]Logenthiran T, Srinivasan D, Khambadkone AM.Multi-agent system for energy resource scheduling of integrated microgrids in a distributed system. Electric Power Systems Research 2011;81(1):138-48.

[66] Kim H, Kinoshita T. A multiagent system for microgrid operation in the grid-interconnected mode. Journal of Electrical Engineering and Technology 2010;5(2):246-54.

[67] Liang H, Choi BJ, Zhuang W, Shen X, Awad A, Abdr A. Multiagent coordina- tion in microgrids via wireless networks. IEEE Wireless Communications 2012;19(3):14-22.

[68] Logenthiran T, Srinivasan D, Khambadkone A, Aung HN. Multiagent system for real-time operation of a microgrid in real-time digital simulator. IEEE Transactions on Smart Grid 2012;3(2):925-33.

[69] A. Costabeber, T. Erseghe, P. Tenti, S. Tomasin, and P. Mattavelli, "'Opti- mization of micro-grid operation by dynamic grid mapping and token ring control,"' in Proc. 14th Eur. Conf. Power Electron. Appl. (EPE), Aug./Sep. 2011, pp. 1-10.

[70] P. A. Madduri, J. Rosa, S. R. Sanders, E. A. Brewer, and M. Podolsky, "Design and verification of smart and scalable DC microgrids for emerg- ing regions,' in Proc. IEEE Energy Convers. Congr. Expo., Sep. 2013, pp. 73-79.

[71] J. Kim, J. M. Guerrero, P. Rodriguez, R. Teodorescu, and K. Nam, "Mode adaptive droop control with virtual output impedances for an inverter- based flexible AC microgrid,' IEEE Trans. Power Electron., vol. 26, no. 3, pp. 689-701, Mar. 2011.

[72] J. Shah, B. F. Wollenberg, and N. Mohan, "Decentralized power flow control for a smart microgrid," in Proc. IEEEPower Energy Soc. General Meeting, Jul. 2011, pp. 1-6.

[73] F. Shahnia, R. Majumder, A. Ghosh, G. Ledwich, and F. Zare, "Operation and control of a hybrid microgrid containing unbalanced and nonlinear loads,' Electr. Power Syst. Res., vol. 80, no. 8, pp. 954965, Aug. 2010.

[74] H. Liang, B. J. Choi,W. Zhuang, and X. Shen, "Stability enhancement of decentralized inverter control through wireless communications in micro- grids," IEEE Trans. Smart Grid, vol. 4, no. 1, pp. 321-331, Mar. 2013.

[75] Y. Gu, X. Xiang,W. Li, and X. He, "Mode-adaptive decentralized control for renewable DC microgrid with enhanced reliability and flexibility," IEEE Trans. Power Electron., vol. 29, no. 9, pp. 5072-5080, Sep. 2014. 